\title{
Installasi Base Transceiver Station (BTS) untuk Jaringan Node B pada Operator Hutchison 3 Indonesia (H3I)
}

\author{
Installation Base Transceiver Station (BTS) to Network Node B at the \\ operator Hutchison 3 Indonesia (H3I)
}

\author{
Uzma Septima, Lince Markis \& Andra Syauqi
}

Jurusan Teknik Elektro Politeknik Negeri Padang Kampus Limau Manis Padang

Telp. 0751-72590 Fax. 0751-72576 Email: andrasyauqi46@ gmail.com

\begin{abstract}
Base Transceiver Station is a device used to connect mobile-phone or smartphone in order to make long-distance communication, although in doing the movement or in transit from one place to another. Installation Base Transceiver Station for Network Node B At the operator Hutchison 3 Indonesia is done to make the operator Hutchison 3 Indonesia signal received by the phone for the better and not dashed when the user performs long-distance communication links with conditions in performing the movement or in the course of one place to another.

Methods beginning the process of physical installation of Base Transceiver Station for Node B network in the operator Hutchison 3 Indonesia and order all the Base Transceiver Station can live well after the battery is connected to a rectifier and the required accuracy when performing the installation Base Transceiver Station. Furthermore, the integration process or Commissioning of the Base Transceiver Station for Node B network operator Hutchison 3 Indonesia on this in order to actively and After Commissioning obtained Receive Signal Level sectoral antennas of -59 dBm which can emit a signal as far as $7 \mathrm{~km}$ to $8 \mathrm{~km}$, after the new process or Pointing connection between this new Base Transceiver Station Base Transceiver Station with preexisting and Pointing between Siak new Base Transceiver Station Base Transceiver Station Perawang with Perawang Students who have a distance of $5 \mathrm{~km}$ Receive Signal level of $-32.4 \mathrm{dBm}$ made in accordance with a budget link provided operator Hutchison 3 Indonesia is $-30 \mathrm{dBm}$ to $-40 \mathrm{dBm}$.
\end{abstract}

Keywords : Base Transceiver Station, Communication Distance, Commissioning, Pointing

\section{PENDAHULUAN}

Perkembangan teknologi telekomunikasi hadir untuk semakin mempermudah hidup manusia dalam hubungan komunikasi jarak jauh antar sesama manusia dengan menggunakan handphone atau smartphone sebagai media untuk melakukan komunikasi jarak jauh tersebut. Ini jauh berbeda dengan 10 tahun yang lalu, bahkan pada saat sekarang ini diseluruh pelosok bahkan sampai ke tingkat pekerjaan yang rendah sekalipun sudah dapat melakukan hubungan komunikasi jarak jauh antar sesama manusia dengan menggunakan handphone. Itu semua karena handphone sudah mudah didapatkan dengan harga yang terjangkau oleh setiap kalangan saat ini.
Handphone ini biasanya menggunakan sistem komunikasi bergerak agar dapat melakukan hubungan komunikasi jarak jauh walaupun dalam melakukan pergerakan atau perjalanan dari suatu tempat ketempat yang lainnya. Sistem komunikasi bergerak ini memungkinkan pelanggannya dapat bergerak selama proses hubungan komunikasi berlangsung dengan catatan pelanggan bergerak dalam cakupan area Base Transceiver Station (BTS) setiap penyelenggara jasa komunikasi yaitu contohnya operator Hutchison 3 Indonesia (H3I).

Di daerah Siak Perawang memang sudah ada sinyal operator Hutchison 3 Indonesia namun tidak terlalu kuat atau putus-putus 
sinyal yang diterima oleh handphone saat pengguna melakukan hubungan komunikasi jarak jauh dengan kondisi dalam melakukan pergerakan atau perjalanan dari suatu tempat ketempat yang lainnya dan penggunapun merasa kurang nyaman dengan hal tersebut, oleh karena itu didaerah tersebut akan dilakukan installasi sebuah Base Transceiver Station baru untuk jaringan Node $B$ atau Generasi Ke-3 (3G) pada operator Hutchison 3 Indonesia supaya sinyal operator Hutchison 3 Indonesia yang diterima oleh handphone menjadi baik dan tidak putus-putus saat pengguna melakukan hubungan komunikasi jarak jauh dengan kondisi dalam melakukan pergerakan atau perjalanan dari suatu tempat ketempat yang lainnya.

Tujuan Penelitian ini adalah:

1. Mengetahui proses installasi fisik dari Base Transceiver Station untuk jaringan Node $B$ pada operator Hutchison 3 Indonesia.

2. Megetahui prosedur integrasi atau Commisioning dari perangkat Base Transceiver Station untuk jaringan Node $B$ pada operator Hutchison 3 Indonesia ini supaya dapat aktif.

3. Mengetahui prosedur penghubungan atau Pointing antara Base Transceiver Station baru ini dengan Base Transceiver Station yang sudah ada sebelumnya dan supaya dapat berjalan sesuai dengan fungsinya.

\section{METODOLOGI}

Sistem komunikasi bergerak memungkinkan pelanggannya dapat bergerak selama proses hubungan komunikasi berlangsung dengan catatan pelanggan bergerak dalam cakupan area penyelenggara jasa komunikasi. Kemampuan mobilitas inilah yang diunggulkan dari sistem komunikasi fixed (diam). Yang jadi permasalahan adalah bagaimana suatu sistem didimensioning agar jaminan komunikasi masih tetap dapat berlangsung meskipun dalam keadaan bergerak dapat berlaku.
Sistem telekomunikasi yang cocok untuk mendukung sistem komunikasi bergerak ini adalah sistem komunikasi tanpa kabel (wireless) yaitu sistem komunikasi radio lengkap dengan antena pemancar dan perangkat radionya. Untuk dapat mengcover cakupan yang begitu luas, dilakukan pembagian coverage area menjadi sub-sub area yang disebut cell. Oleh karena itulah sistem komunikasi bergerak disebut juga sistem komunikasi selluler.

Permasalahannya adalah bagaimana caranya agar tiap-tiap sub area tersebut dapat saling berkomunikasi sehingga pelanggan dimanapun dia, selama masih dalam coverage sub area (cell) hubungan komunikasi masih dapat dilakukan. Oleh karena itu, dalam tiap sub area (cell) harus ada dua perangkat radio, yang pertama untuk komunikasi cell dengan pelanggan yang ada di wilayahnya dan perangkat radio yang kedua digunakan untuk hubungan komunikasi antar sub area (cell).

Idealnya bentuk cell adalah heksagonal agar seluruh ruangan ter-cover, tetapi kenyataannya di lapangan bentuk cell adalah lingkaran sehingga ada celah antara cell yang tidak tercover oleh jaringan. Daerah ini disebut daerah blank spot, dimana pada daerah ini pelanggan tidak dapat melakukan hubungan komunikasi.

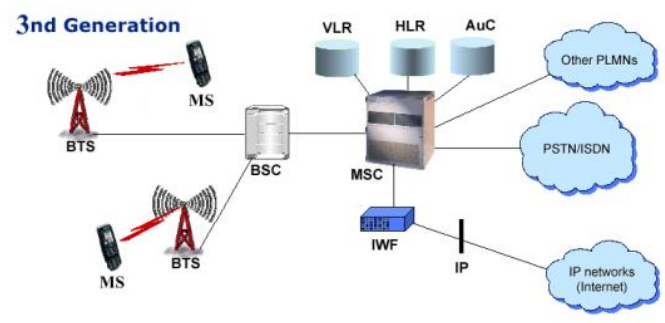

Gambar 1. Struktur Sistem Komunikasi Bergerak

\section{MS (Mobile Station)}

Pada umumnya terdapat tiga jenis MS untuk sistem komunikasi bergerak. Pertama adalah pesawat yang terhubung dengan kendaraan (vehicle mountered). Kedua 
pesawat portable dan yang terakhir pesawat genggam (handheld). Secara arsitektur MS terdiri dari bagian yang menangani radio, bagian pemrosesan data dan antarmuka dengan pengguna atau ke terminal yang lain. Dua bagian yang pertama berfungsi untuk mengakses dan berinteraksi dengan jaringan melalui radio interface. Sedangkan yang terakhir berkaitan dengan interaksi dengan pengguna.

\section{BTS (Base Transceiver Station)}

Base transceiver Station terdiri dari perlengkapan radio yang diperlukan untuk mendukung sebuah sel.Tugas dari BTS adalah menjaga dan memonitor hubungan dengan MS. Lebih khusus lagi, menghubungkan dengan transmisi penerimaan radio, semua fungsi pemrosesan sinyal spesifik dengan radio interface dan beberapa fungsi tambahan. BTS juga sering disebut sebagai kepanjangan tangan BSC dan merupakan bagian dengan perangkat keras tesebut.

\section{TCE (Transcoding Equipment)}

Dengan adanya TCE maka frekuensi radio dapat digunakan secara lebih efektif. Dalam jaringan GSM suara ditransmisikan hanya $16 \mathrm{Kbps}$ (13 Kbps informasi suara dan 3 kbps informasi kontrol), sedangkan pada jaringan tetap (ISDN) biasanya digunakan standard transmisi $64 \mathrm{Kbps}$ (PCM 8 bit). Tugas dari TCE antara lain adaptasi bit rate antara BSC dan MSC. Hubungan informasi kontrol (SS7) dan adaptasi rate untuk transmisi data melalui telepon mobile. Beberapa literature menyebutnya sebagai TRAU (Transcoder Rate Adaptation Unit) dan dalam arsitektur kanonik GSM diklasifikasikan sebagai bagian dari BTS.

\section{BSC (Base Station Controller)}

Dalam terminology GSM, suatu BSS adalah gabungan sebuah BSC dan semua BTS yang dikontrolnya. BSC berfungsi untuk memonitor dan mengontrol sejumlah BTS. Jadi semua pengaturan kanal pada radio interface (pengalokasian/pelepasan kanal) dan mekanisme handover dilakukan secara remote oleh BSC. Dengan adanya proses ini maka BSC dapat mengendalikan kinerja transmisi setiap BTS dan jika perlu dapat memerintahkan handover ke sel (BTS yang lain yang masih dalam wilayah BSC yang bersangkutan. Jika suatu intra MSC handover diperlukan, BSC melibatkan MSC (Mobile service Switching Centre) untuk menjalankan handover.

Handover berarti perubahan yang terjadi jika mobile station meninggalkan suatu wilayah sel dengan kata lain berpindahnya MS dari satu sel ke sel lainnya tanpa memutuskan hubungan yang sedang berlangsung. Sedangkan intra MSC handover berarti suatu handover yang terjadi antara dua sel yang dikontrol oleh MSC yang sama tapi dengan BSC yang berbeda. Suatu BSC dapat menangani beberapa BTS tergantung dari karakteristik trafik pada lokasi pelayanan.

\section{MSC (Mobile Switching Center)}

MSC pada intinya adalah suatu peralatan switching, ekivalen dengan sentral digital (ISDN) ditambah dengan pengaturan mobilitas pelanggan. Fungsi utamanya adalah untuk kordinasi panggilan dating dari/ke pelanggan GSM termasuk fungsi call routing dan call control. Lebih spesifik fungsi ini bertanggung jawab atas pengalokasian dan pelepasan kanal radio melalui BSC beserta mekanisme location updating, handover dari satu sel ke sel yang lainnya, serta interkoneksi dengan jaringan lain (ISDN/PSTN).

\section{a. VLR (Visitor Location Register)}

informasi pelanggan dan bagian dari informasi mobile station yang mengijinkan menerima panggilan-panggilan untuk diarahkan ke pelanggan bergerak. VLR menyimpan MSRN, TMSI, area lokasi, data pada layanan-layanan tambahan, IMSI, nomor MS ISDN, alamat-alamat HLR atau GT, dan identitas MS setempat, jika digunakan. 


\section{b. HLR (Home Location Register)}

HLR adalah tempat penyimpanan dan administrasi pelanggan yang diperlukan untuk menyediakan service (ekivalen dengan sentral lokal pada jaringan tetap ). Fungsi dasarnya adalah untuk menyediakan referensi lokasi MS pada wilayah GSM. Ketika pelanggan harus dicari (call setup), HLR akan diinterogasi unuk memberikan informasi yang relevan.

\section{c. EIR (Equipment Identity Register)}

Setiap pesawat GSM mempunyai nomor identitas yang dilakukan secara perangkat keras (IMEI). Dalam mengakses jaringan, pesawat akan mengirim pesan permintaan akses disertai dengan nomor pesawat yang bersangkutan. Jaringan akan memberikan nomor ini bila nomor pesawat tersebut tidak terdaftar dalam EIR, maka akses ke jaringan akan dapat dilakukan.

\section{d. AUC (Authentication Center)}

Authentication Center memproteksi sistem GSM terhadap penggunaan ilegal (oleh bukan pelanggan). AuC juga memproteksi sistem terhadap penyalahgunaan data pelanggan GSM. AuC terdiri dari suatu bank data unit kontrol dan monitor (untuk pemeriksaan hak akses lain) dan perangkat keras khusus untuk menjalankan algoritma enkripsi.

\section{Pengertian dan Perkembangan SKB}

Huruf "G" pada setiap penamaan di atas merujuk pada generasi, hal ini berarti bahwa $1 \mathrm{G}$ berarti Generasi pertama, 2G generasi kedua, dan selajutnya. Pasti pembaca bertanya-tanya, "generasi dari apa?" Banyak sumber blog yang hanya menyebutkan bahwa 1G, 2G, 3G adalah urutan dari generasi, tapi tidak menyebutkan generasi dari apa. Yang dimaksud dengan generasi disini adalah generasi dari teknologi layanan data dan komunikasi wireless, khususnya untuk mobile phone.

Dari masa ke masa, teknologi komunikasi wireless ini mengalami perkembangan. Maka dapat dipastikan bahwa semakin besar angkanya semakin canggih pula teknologinya dan semakin banyak kemudahan yang kita peroleh. Perbedaan yang paling mendasar diantara generasigenerasi tersebut adalah dalam hal kecepatan unduh data. Dimana pada $1 \mathrm{G}$ kecepatan unduh hanya berkisar antara 9,6 kbps sedangkan pada 3,5 G mencapai 10 Mbps.

\section{1G (Generasi Pertama)}

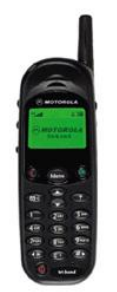

Gambar 2. HP Generasi Pertama

Jaringan $1 \mathrm{G}$ pertamakali ditemukan di tahun 1980 ketika AMPS di Amerika bekerjasama dengan TACS dan NMT di Eropa membuat terobosan di teknologi jaringan. 1G ini adalah standar baru dari teknologi jaringan. Zaman dimana campur tangan manusia sudah tidak terlalu dibutuhkan semuanya benar benar sudah otomatis dan dengan bentuk yang kecil tentunya. Karena ini adalah ponsel generasi pertama mereka membuatnya sangat serius mereka membuat ponsel yang kuat dan handal yang akhirnya tersebar ke seluruh dunia.

\section{2G (Generasi Kedua)}

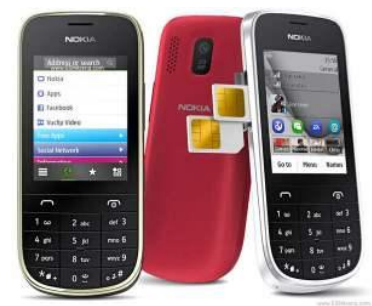

Gambar 3. HP Generasi Kedua

Pada awal tahun 90-an untuk pertama kalinya muncul teknologi jaringan seluler digital. yang hampir bisa dipastikan memiliki banyak kelebihan dibandingkan dengan teknologi jaringan analog (1G) seperti suara 
lebih jernih, keamanan lebih terjaga dan kapaistas yg lebih besar. GSM muncul terlebih dahulu di Eropa sementara Amerika mengandalkan D-AMPS dan Quallcomm CDMA pertama mereka. kedua sistem ini (GSM dan CDMA) mewakili generasi ke dua (2G) dari teknlogi jaringan nirkabel.

Generasi kedua memiliki memiliki fitur CSD sehingga transfer data lebih cepat dengan kecepatan sekitar 14.4 kbps. Pada generasi $2 \mathrm{G}$ ini pemilik juga dapat mengirimkan pesan teks melaui handphone sehingga tidak memerlukan pager lagi. Akan tetapi Fitur CSD ini membuat Tagihan bualanan membengkak karena jika ingin terhubung ke internet harus menggunakan dialup yang dihitung permenit.

\section{$2.5 G$}

GPRS (The General Packet Radio Service) - 2.5G - adalah terobosan terbaru di generasi ke dua ini, lahir pada tahu 1997 GPRS dengan sigap menggantikan CSD yang boros. Dengan GPRS bisa dipastikanbahwa pengguna akan "Always on". Pengguna dapat terhubung ke internet dimana saja dan kapan saja. Secara teori kecepatan GPRS mampu mencapai $115 \mathrm{kbps}$ walau kenyataan kini berkata lain. GPRS juga membuat pengguna lebih hemat karena hitungannya menjadi per kilobyte bukan lagi permenit seperti CSD. Fasilitas yang diberikan oleh GPRS antara lain e-mail, mms, browsing, dan internet.

\section{$2.75 G$}

Antara tahun 2001 sampai 2003, EVDO Rev 0 pada CDMA2000 dan UMTS pada GSM pertama yang merupakan cikal bakal dari $3 \mathrm{G}$ mulai diperkenalkan. Tapi ini bukan berarti GPRS telah mati. Justru saat muncul EDGE (Enhanced Data rates for GSM Evolution) ini diharapkan akan menjadi pengganti GPRS yang baik, karena tidak perlu mengupgrade hardware secara ekstrem dan tidak terlalu banyak mengeluarkan biaya. Dengan EDGE pengguna sudah dapat merasakan kecepatan dua kali lebih cepat daripada GPRS akan tetapi tetap saja masih kurang cepat dari $3 \mathrm{G}$.

EDGE (Enhanced Data for Global Evolution) : teknologi perkembangan dari GSM, rata-rata memiliki kecepatan 3kali dari kecepatan GPRS. Kecepatan akses EDGE secara teori sekitar 384kbps. Fasilitas yang disediakan EDGE sama seperti GPRS. Beberapa sumber menyebutkan bahwa EDGE ini termasuk ke dalam $2.75 \mathrm{G}$, sehingga ia adalah peralihan dari $2 \mathrm{G}$ ke $3 \mathrm{G}$.

\section{3G (Generasi Ketiga)}

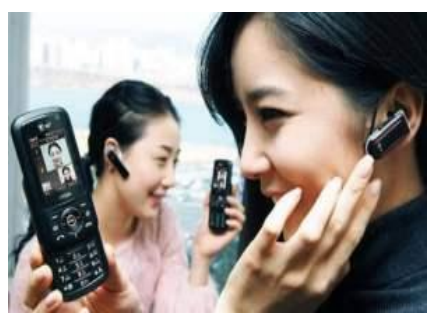

Gambar 4. Video Call dengan 3G

UMTS (Universal

Mobile Telecommunication Service) adalah perkembangan lebih lanjut dari EDGE. UMTS sering disebut generasi ke tiga (3G). Selain menyediakan fasilitas akses internet (e-mail, mms, dan browsing), UMTS juga menyediakan fasilitas video streaming, video conference, dan video calling). Secara teori kecepatan akses UMTS sekitar 480kbps.

\section{$3.5 G$}

HSDPA (High Speed Downlink Packet Access) merupakan perkembangan akses data selanjutnya dari 3G. HSDPA sering disebut dengan generasi 3.5 (3.5G) karena HSDPA masih berjalan pada platform 3G. Secara teori kecepatan akses data HSDPA sama seperti 480kbps, tapi pastinya HSDPA lebih cepat.

Setelah beberapa tahun, CDMA 2000 mengupgrade teknologi jaringan evdo mereka. menjadi EVDO rev A. teknologi ini memiliki kecepatan 10 kali lebih cepat dari evdo rev 0. Juga UMTS yang menguprade 
teknologi mereka ke HSDPA dan HSUPA. inilah yang dinamakan 3.5G.

\section{4G (Generasi Keempat)}

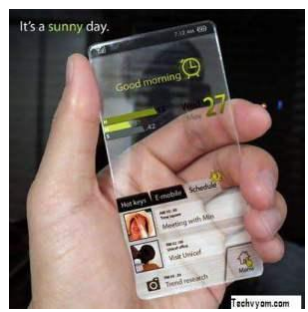

Gambar 5. HP Generasi Keempat

4G adalah singkatan dari istilah dalam bahasa Inggris: fourth-generation technology. Istilah ini umumnya digunakan mengacu kepada pengembangan teknologi telepon seluler. 4G merupakan pengembangan dari teknologi 3G. Nama resmi dari teknologi $4 \mathrm{G}$ ini menurut IEEE (Institute of Electrical and Electronics Engineers) adalah " $3 G$ and beyond".

4G yang digadang gadang 500 kali lebih cepat daripada CDMA2000 dapat memberikan kecepatan hingga $1 \mathrm{Gbps}$ jika anda di rumah atau 100Mbps ketika bepergian. Dapat dibayangkan betapa cepatnya akses data yang kita dapatkan, dapat dipastikan bahwa teknologi komunikasi generasi keempat ini semakin memperkecil dunia. Selain itu ini adalah salahsatu solusi yang paling efektif untuk jaringan internet dipedasaan karena lebih baik menanam 1 menara $4 \mathrm{G}$ untuk ber milmil jauhnya, daripada dengan menyelimuti sawah-sawah dengan kabel fiber optik.

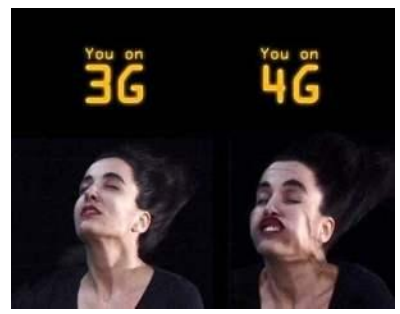

Gambar 6. Perbedaan 3G dan 4G

\section{Operator-Operator yang Ada Di Indonesia}

Telepon seluler atau yang biasa disingkat dengan sebutan ponsel memiliki istilah lain yaitu handphone, hp, telepon nirkabel, telepon genggam, dan lain sebagainya. Benda elektronik yang memiliki fungsi utama sebagai alat telekomunikasi ini telah banyak digunakan oleh masyarakat kita. Karena fungsinya yang sangat penting untuk berhubungan antara orang yang satu dengan yang lain, maka sekarang ini ponsel telah menjadi salah satu barang wajib nasional yang penting untuk dimiliki setiap orang.

Setiap telepon seluler atau handphone membutuhkan layanan dari suatu operator layanan telekomunikasi yang sesuai untuk dapat beroperasi dengan baik. Di indonesia terdapat banyak operator telepon seluler resmi yang menjual layanannya dalam bentuk produk kartu perdana yang umumnya berisi nomor telepon dan juga menjual jasa komunikasi dalam bentuk suara, pesan teks tertulis, data, sambungan internet, dan lain sebagainya. Semua operator berlombalomba menarik konsumen dengan berbagai cara mulai dari menawarkan tarif yang murah sampai membentuk produk khusus untuk komunitas tertentu.

Kita sebagai konsumen memang tidak ada salahnya untuk mengetahui operator telepon nasional apa saja yang ada di Indonesia. Dari sanalah kita dapat membandingkan satu sama lain sesuai kondisi riil di lapangan sesuai daerah tempat tinggal kita. Mana yang terbaik dapat kita pilih dan kita jadikan sebagai operator telepon utama untuk handphone kita. Sedangkan yang lainnya dapat digunakan sebagai operator cadangan atau operator kedua untuk hp kita.

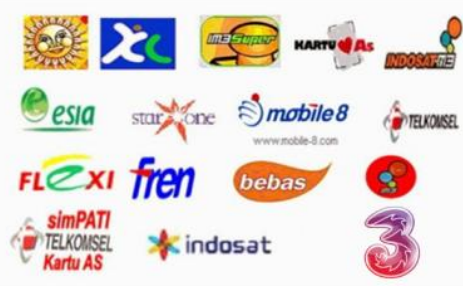

Gambar 7. List Operator 
Operator-operator ini adalah perusahaan dambaan banyak insinyur muda, tempat kerja yang menjadi idaman banyak sarjana telekomunikasi baik dari kampus negeri terkenal hingga yang kurang dikenal (semoga pernyataan ini tidak salah CMIIW ). Di sini karyawan bertindak sebagai penyelenggara jaringan telekomunikasi untuk customer langsung.

\section{Installasi Base Transceiver Station (BTS)}

Dalam melakukan penginstallasian BTS, ada beberapa tahap yang harus kita lakukan, yaitu installasi fisik dari BTS, integrasi perangkat BTS, Penghubungan BTS baru dengan BTS yang sudah ada dan pengujian BTS setelah selesai diinstall dan dihubungkan. Dalam installasi BTS ini harus berjalan sesuai dengan tahapan-tahapan yang ada, jika sudah selesai tahapan yang pertama baru bisa lanjut ke tahapan-tahapan selanjutnya.

Sebelum kita melakukan installasi kita harus mengetahui perangkat-perangkat yang akan kita pasang pada saat installasi nantinya, perangkat-perangkatnya yaitu:

Tabel 1. Antena-Antena yang Digunakan

\begin{tabular}{|c|c|c|c|c|c|}
\hline $\begin{array}{c}\text { Ite } \\
\text { m }\end{array}$ & $\begin{array}{c}\text { Ant } \\
\text { ena } \\
\text { Typ } \\
\text { e }\end{array}$ & $\begin{array}{c}\text { Le } \\
\text { ng } \\
\text { th }\end{array}$ & $\begin{array}{c}\text { Antena } \\
\text { Inform } \\
\text { ation }\end{array}$ & $\begin{array}{c}\text { Ante } \\
\text { na } \\
\text { Eleva } \\
\text { tion } \\
\text { (m) }\end{array}$ & $\begin{array}{c}\text { Azimu } \\
\text { th }\end{array}$ \\
\hline 1 & RF & & Huawei & 40.0 & $80^{\circ}$ \\
\hline 2 & RF & & Huawei & 40.0 & $200^{\circ}$ \\
\hline 3 & RF & & Huawei & 40.0 & $310^{\circ}$ \\
\hline 4 & MW & 0.3 & Huawei & 39,0 & 246,06 \\
\hline
\end{tabular}

Tabel 2. Perangkat-Perangkat yang Digunakan

\begin{tabular}{|c|c|c|c|}
\hline $\begin{array}{c}\text { Ite } \\
\text { m }\end{array}$ & $\begin{array}{c}\text { Client } \\
\text { Name }\end{array}$ & Type & $\begin{array}{c}\text { Manufa } \\
\text { ctur }\end{array}$ \\
\hline 1 & Rectifier & & Huawei \\
\hline 2 & BTS & $3 \mathrm{G}$ & Huawei \\
\hline
\end{tabular}

\section{Installasi Fisik dari BTS}

Dalam installasi fisik dari BTS ini kita akan memulai installasi antenna sectoral terlebih dahulu, setelah itu baru lanjut ke installasi microwave dan pemasangan perangkat BTS. Langkah-langkahnya yaitu:

\section{Installasi Antena Sectoral}

- Langkah awal pada installasi Antena Sectoral ini yaitu, pasangkan kabel Tx dan Rx nya terlebih dahulu setelah itu baru lanjut pemasangan mounting untuk antena sectoral untuk penyangga antenna diatas tower nantinya dan Siapkan tali tambang yang telah terhubung dengan katrol diatas tower, setelah itu ikat tali tambang tersebut ke antenna sectoral setelah itu tarik tali tambang tersebut.

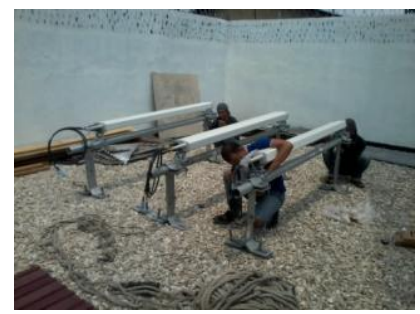

Gambar 8. Pemasangan Mounting Antena Sectoral

- Lalu jika antenna sectoral telah sampai ke ketinggian tower yang telah ditentukan, lalu pasangkan mounting antenna sectoral ke tower tersebut dengan menggunakan kunci-kunci

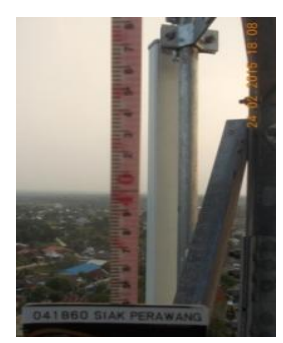

Gambar 9. Antena Sectoral yang Telah Terpasang

- Arahkan setiap antenna sesuai dengan azimutnya masing-masing yang telah ditentukan. 


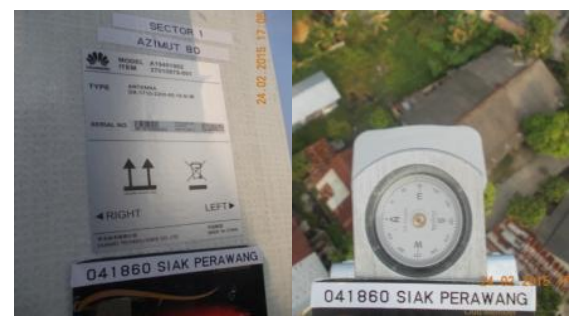

Gambar 10. Azimuth Antena Sectoral Sector

- lalu ukur juga kemiringan antenna sectoral menggunakan angel meter, atur sesuai dengan ukuran yang telah ditentukan.

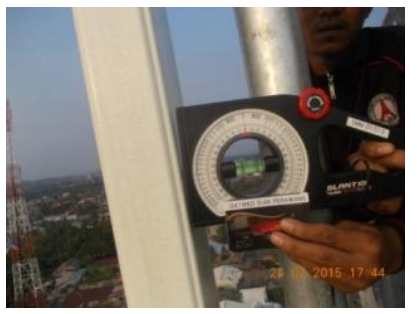

Gambar 11. Pengukuran Kemiringan Antena Sectoral

- Lalu hubungkan antenna sectoral ini ke perangkat BTS (WRFU) dengan kabel feeder.

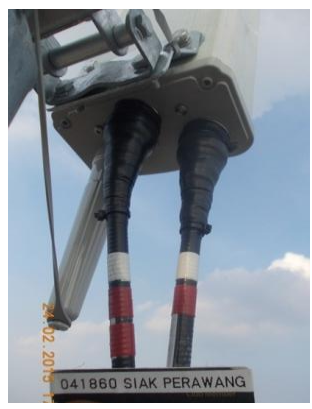

Gambar 12. Antena Sectoral yang Terpasang Kabel Feeder

- Setelah itu kabel feeder itu akan masuk keperangkat BTS (WRFU).

\section{Installasi Antena Microwave}

- Langkah awal pada installasi Antena Microwave ini yaitu, pasangkan ODU ke antena microwave sesuai dengan Polarisasinya yaitu Horizontal atau Vertikal dan siapkan tali tambang yang telah terhubung dengan katrol diatas tower, setelah itu ikat tali tambang tersebut ke antenna microwave tersebut.

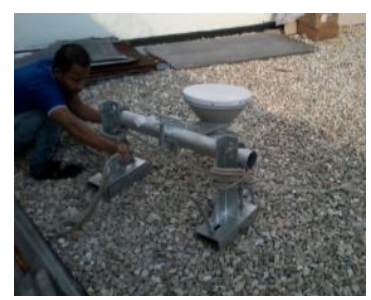

Gambar 13. Pengikatan Tali Tambang ke Antena Microwave

- Setelah itu tarik tambang dari bawah hingga antenna microwave sampai ke ketinggian tower yang telah ditentukan.

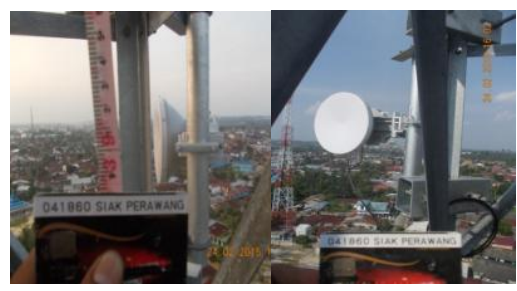

Gambar 14. Antena Microwave Telah Terpasang

- Arahkan antenna sesuai dengan azimuthnya yang telah ditentukan.

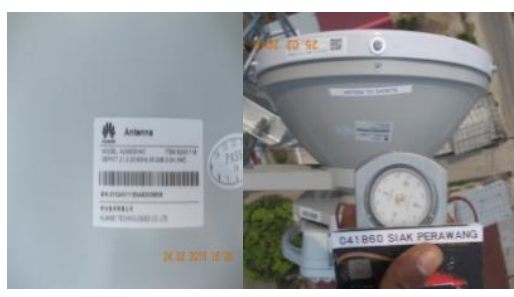

Gambar 15. Azimuth Antena Microwave

- Lalu hubungkan antenna microwave ini (ODU) ke perangkat BTS (IDU/ISU) dengan kabel coaxial.

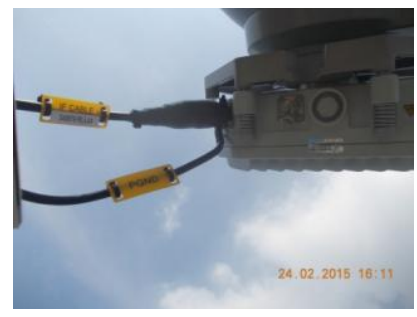

Gambar 16. ODU yang Terpasang Kabel Coaxial 
- Setelah itu kabel coaxial itu akan masuk keperangkat BTS (ODU).

\section{Pemasangan Perangkat BTS}

Kabel feeder dan kabel coaxial tadi akan masuk kedalam perangkat BTS, BTS ini yang akan mengaktifkan dan mengatur setiap antenna yang berada diatas tower nantinya.

- Langkah awal pada installasi perangkat BTS ini yaitu, buatkan kedudukan untuk peletakan kulkas dari Rectifier dan BTS $3 \mathrm{G}$.

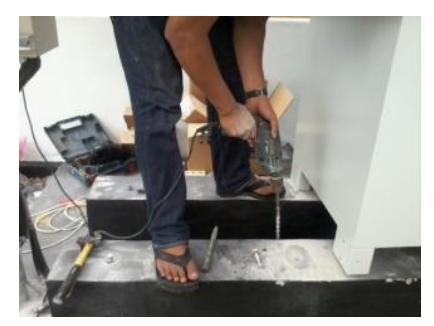

Gambar 17. Pembuatan Kedudukan untuk Rectifier dan BTS 3G

- Pasangkan semua perangkat pada Rectifier yang berfungsi sebagai penyearah tegangan dari tegangan (AC) yang berasal dari ACPDB dikonversikan ke dalam tegangan searah (DC) untuk di komsumsi oleh BTS nantinya.

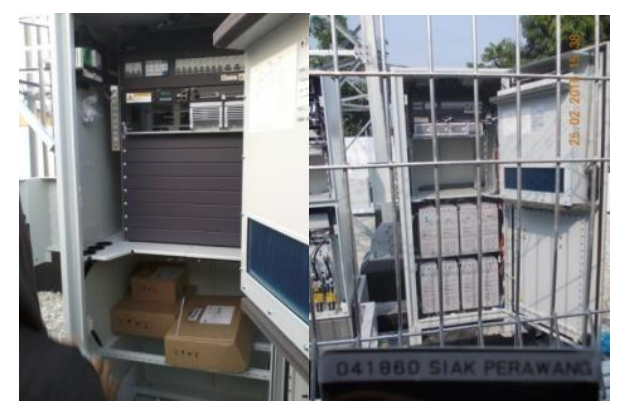

Gambar 18. Sebelum dan Sesudah Pemasangan Perangkat Rectifier

- Pasangkan semua perangkat pada BTS 3G yang menjadi inti dari sebuah BTS yang akan menjadikan sebuah BTS berfungsi sebagaimana mestinya. Perangkat-perangkatnya yaitu berupa WMPT, ISU/IDU dan WRFU.

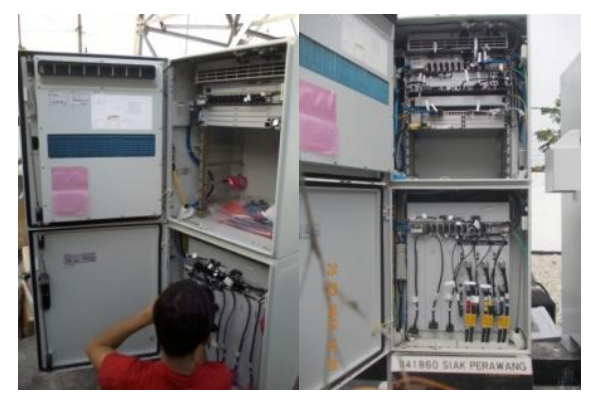

Gambar 19. Sebelum dan Sesudah Pemasangan Perangkat BTS $3 \mathrm{G}$

\section{Integrasi Perangkat dari BTS}

Setelah melakukan installasi fisik dari BTS dengan baik dan benar maka baru kita dapat melanjutkan ke tahapan integrasi perangkat atau disebut dengan Commisioning dari BTS dengan menggunakan software Local Maintenance Terminal (LMT), langkah-langkahnya yaitu:

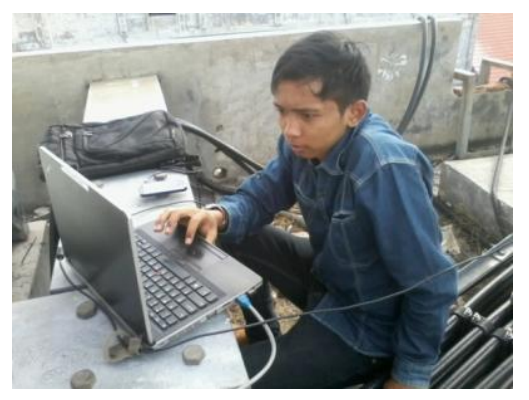

Gambar 20. Integrasi Perangkat Menggunakan Laptop

- Port Eth Modul WMPT tadi dihubungkan ke laptop dengan menggunakan kabel UTP setelah itu baru masukan ip address dan netmasknya yaitu :

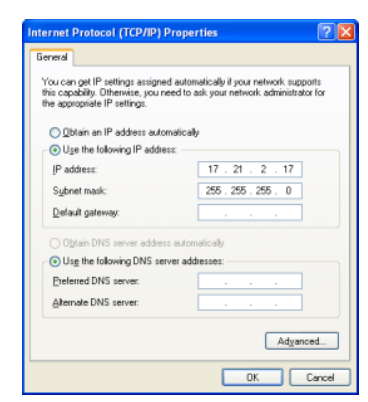

Gambar 21. Ip Address dan Netmask yang Digunakan 
- Login user LMT terlebih dahulu, sesuai dengan user dan password yang telah ditentukan.

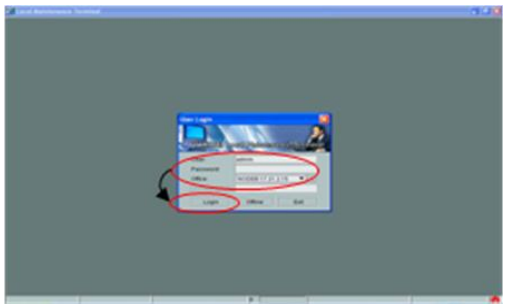

Gambar 22. Login User LMT

- Cari file konfiguasi Node $B$ atau berupa script yang akan kita upload ke Node B.

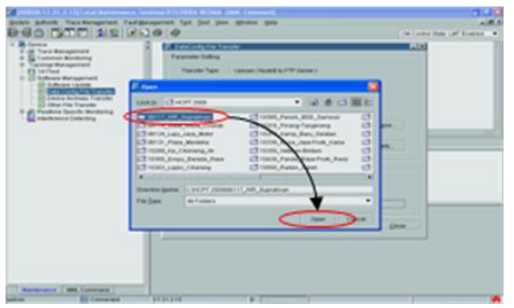

Gambar 23. Upload File Konfigurasi Node B

- Buka folder file konfigurasi Node $B$ tersebut.

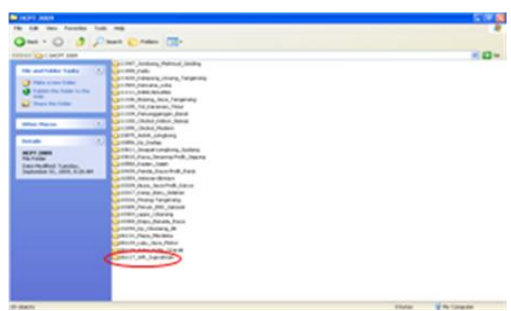

Gambar 24. Folder File Konfigurasi Node B

- Proses peng-upload-an file konfigurasi Node $B$ tersebut selesai dilakukan.

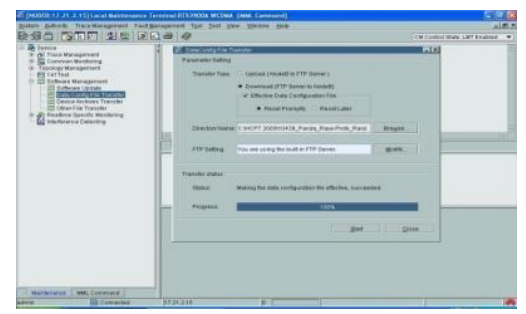

Gambar 25. Proses Upload File Telah Selesai

- Setelah selesai proses peng-upload-an script/file konfigurasi Node B tersebut, baru kita cek lewat smartphone yang menggunakan kartu H3I yaitu dengan menggunakan software G-Moon untuk melihat CID dan RXL dari tiap-tiap sector.
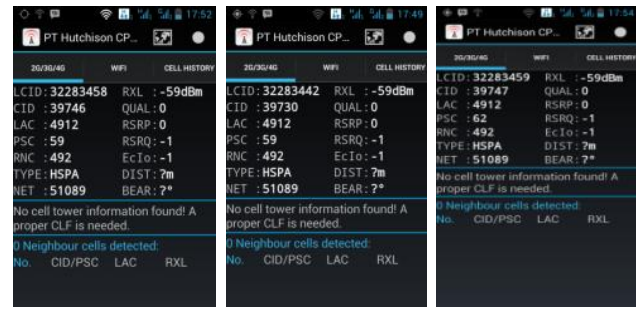

Gambar 26. Pengecekan Sector dengan Software G-Moon

\section{Penghubungan Antara BTS Baru dengan BTS yang Sudah Ada.}

Setelah melakukan integrasi perangkat dari BTS dengan baik dan benar maka baru kita dapat melanjutkan ke tahapan penghubungan BTS yang baru diinstall ini (BTS Siak Perawang) dengan BTS yang sudah ada dan aktif (BTS Pelajar Perawang) atau disebut Pointing dengan menggunakan software iManager U2000 Web LCT, langkah-langkahnya yaitu :

- Antena microwave BTS Siak Perawang dengan semua perangkatnya telah aktif dan siap dihubungkan dengan Antena microwave BTS Pelajar Perawang.

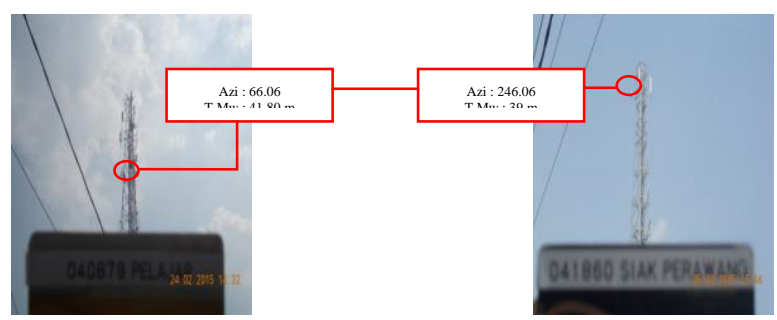

Gambar 27. Antena Microwave Dikedua BTS

- Atur ip address dan netmask kembali karena untuk pointing ini ip address dan netmask yang digunakan berbeda dengan yang kita gunakan sebelumnya. 


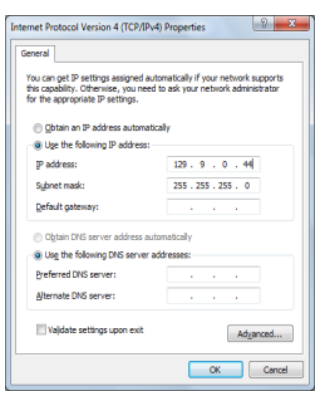

Gambar 28. Ip Address dan Netmask yang Digunakan

- Login user LCT terlebih dahulu, sesuai dengan user dan password yang telah ditentukan.

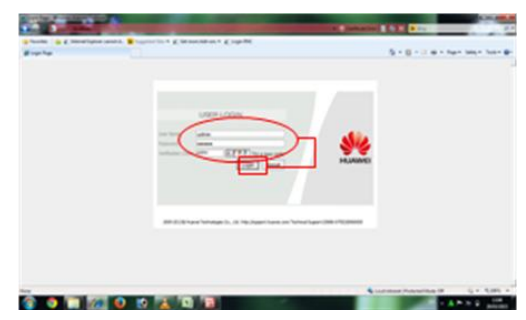

Gambar 29. Login User LCT

- Lakukan pointing sesuai dengan budget link (RSL=30-40 $\mathrm{dBm})$ yang telah ditentukan, atur antenna microwave hingga $\mathrm{RX}$ Power $(\mathrm{dBm})$ sesuai dengan budget link.

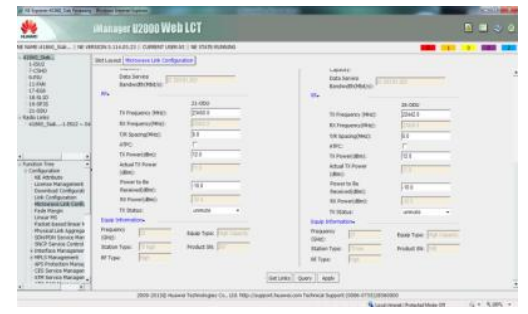

Gambar 30. RSL Sesuai dengan Budget Link

\section{HASIL DAN PEMBAHASAN}

Setelah BTS selesai diinstall dan dihubungkan dengan BTS yang sudah ada dan dapat aktif sesuai dengan fungsifungsinya, maka baru kita lakukan pengujian terhadap BTS $3 \mathrm{G}$ ini.

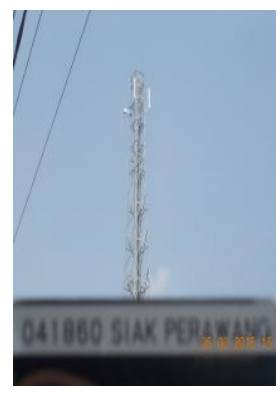

Gambar 31. Tower Beserta Antena Selesai Diinstallasi

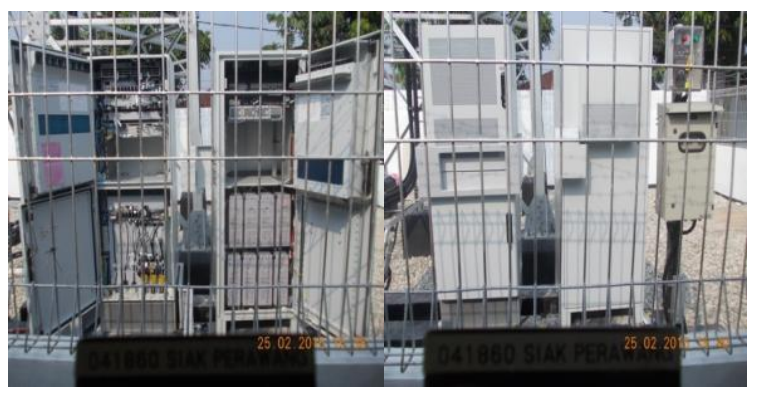

Gambar 32. Perangkat BTS Selesai Diinstallasi

Pengujian jaringan 3G setelah BTS selesai diinstall yaitu kita uji lewat smartphone yang menggunakan kartu H3I atau 3 dengan melakukan Video Call dengan pengguna smartphone lainnya.

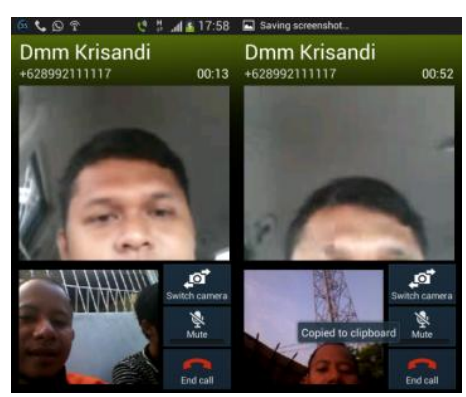

Gambar 33. Video Call pada Jaringan Node B

\section{SIMPULAN}

1. Agar semua perangkat Base Transceiver Station dapat hidup dengan baik setelah dihubungkan ke Rectifier maupun baterai maka diperlukan ketelitian saat melakukan installasi Base Transceiver Station.

2. Setelah melakukan Commisioning didapatkan Receive Signal Level antena-antena sectoral sebesar $-59 \mathrm{dBm}$ 
yang dapat memancarkan sinyal sejauh $7 \mathrm{~km}$ sampai dengan $8 \mathrm{~km}$.

3. Pointing antara Base Transceiver Station baru Siak Perawang dengan Base Transceiver Station Pelajar Perawang yang mempunyai jarak $5 \mathrm{~km}$ Receive Signal Levelnya dibuat sebesar -32.4 dBm sesuai dengan budget link yang disediakan operator Hutchison 3 Indonesia yaitu $-30 \mathrm{dBm}$ sampai dengan $-40 \mathrm{dBm}$.

\section{DAFTAR PUSTAKA}

Barkah, Ahmad. 2014. Perangkat-perangkat Tower BTS. (http://ahmadbarkah1.blogspot.com/201 4/07/perangkat-perangkat-towerbts.html, Diakses 20 Maret 2015).

Buciyasi, Nur Faudzi. 2013. Pengertian Sistem Komunikasi Bergerak (Online), (http://nfbuciyasi28.blogspot.com/2012/ 05/pengertian-sistem-komunikasibergerak.html, Diakses 10 maret 2015).

Ernanto, Alfian Dwi. 2014. Perkembangan Gsm Dari Awal Hingga 4 G. (http://www.academia.edu/7496734/PER KEMBANGAN_GSM_DARI_AWAL_ HINGGA_4G, Diakses 20 Maret 2015).

Organisasi.Org. 2014. Daftar Operator Telepon/Handphone GSM dan CDMA di Indonesia. (http://www.organisasi.org/1970/01/daft ar-operator-telepon-handphone-gsmdan-cdma-di-indonesia.html, Diakses 20 Maret 2015).

Vikrinubageur. 2012. Komunikasi Bergerak (Online). (http://tutorialtelkom.blogspot.com, Diakses 10 Maret 2015). 